\title{
Seasonal variations of heavy metals concentrations and pollution assessment of major dumpsites in Ilisan-Remo, Nigeria
}

\author{
Oluwatosin Sarah Shokunbi ${ }^{1,2^{*}}{ }^{\mathbb{D}}$, Olubode Olumuyiwa Ajayi ${ }^{2}$, Olutayo Sunday Shokunbi ${ }^{3 \oplus}$ \\ ${ }^{1}$ Chemistry Unit, Department of Basic Sciences, Babcock University, Ogun State, Nigeria \\ ${ }^{2}$ Department of Chemistry, Federal University of Technology, Akure, Ondo State, Nigeria \\ ${ }^{3}$ Department of Biochemistry, Babcock University, Ogun State, Nigeria
}

\begin{abstract}
Background: Globally, natural and anthropogenic activities have led to soil pollution resulting in physiological and health challenges on environment, plants, animals, and humans. The present study was conducted to determine the total levels of heavy metals including cadmium $(\mathrm{Cd})$, copper $(\mathrm{Cu})$, chromium $(\mathrm{Cr})$, lead $(\mathrm{Pb})$, and nickel $(\mathrm{Ni})$, in two major dumpsites in Ilisan-Remo, Ogun State, Nigeria. Methods: Sixteen composite soil samples were collected from both dumpsites (Cargo and Ilisan) at depths of $0-15 \mathrm{~cm}$. Samples were collected in the wet and dry seasons. After collecting samples, they were air-dried and sieved, and the concentrations of metals were evaluated using flame atomic absorption spectrometry (FAAS). The obtained data were used to determine the pollution indices including contamination factor (CF), geo-accumulation index (Igeo), and ecological risk index.

Results: The concentrations of heavy metals in Cargo dumpsite followed this order: $\mathrm{Cr}>\mathrm{Pb}>\mathrm{Cu}>\mathrm{Ni}$ $>\mathrm{Cd}$, during wet and dry seasons. Conversely, the concentrations of heavy metals in Ilisan dumpsite followed this order: $\mathrm{Pb}>\mathrm{Cr}>\mathrm{Cu}>\mathrm{Cd}>\mathrm{Ni}$, over both seasons. The measured $\mathrm{CF}$ levels for both Cargo and Ilisan dumpsites were low to very high for $\mathrm{Cd}$ over both seasons. The Igeo revealed that both dumpsites were moderately to heavily polluted by $\mathrm{Cd}$ and Ilisan dumpsite was moderately polluted by $\mathrm{Pb}$. A low to considerable ecological risk was observed for both dumpsites.

Conclusion: The pollution indices suggest that both dumpsites were heavily polluted by $\mathrm{Cd}$ due to anthropogenic activities. Appropriate measures should be implemented to manage these dumpsites. Keywords: Anthropogenic activities, Dumpsite soils, Heavy metals, Pollution index

Citation: Shokunbi OS, Ajayi OO, Shokunbi OS. Seasonal variations of heavy metals concentrations and pollution assessment of major dumpsites in Ilisan-Remo, Nigeria. Environmental Health Engineering and Management Journal 2020; 7(3): 193-202. doi: 10.34172/EHEM.2020.22.
\end{abstract}

\section{Article History:}

Received: 29 May 2020

Accepted: 22 July 2020

ePublished: 15 September 2020

\section{Introduction}

Pollution is a global problem which its impact on human health is significant (1). Pollutants released from industrial effluent and automobiles in overpopulated cities have been increased, resulting in adverse impacts on human health and the environment $(1,2)$. Heavy metals are common environmental pollutants and exposure to their significant levels can result in deleterious effects on humans $(3,4)$. Environmental monitoring of soil is critical in understanding the impact of metal and soil interactions, as well as determining the potential accumulation in plants, resulting in food safety problems and potential human health risks (5).

Heavy metals encompass metals with densities higher than $5 \mathrm{~g} / \mathrm{cm}^{3}$ (6). Pollution associated with heavy metals and the resultant deleterious health effects on humans following exposure, have provided some motivations for global research efforts (6,7). Although few heavy metals are vital to human health, exposure to elevated concentrations of these metals can lead to deleterious effects (6). Heavy metals essential for plant growth include $\mathrm{Co}, \mathrm{Cu}, \mathrm{Fe}, \mathrm{Mo}$, and $\mathrm{Zn}$. Essential elements for animals include $\mathrm{Cr}, \mathrm{Ni}$, and $\mathrm{Zn}$. The elements $\mathrm{Cd}, \mathrm{Hg}$, and $\mathrm{Pb}$ can be deleterious at significant concentrations and have been shown to be non-essential for plants and animals (7). Heavy metals contaminating the food chain have been an intense incident in the past few years owing to their ability to accumulate in the soil, air, and water in bio-systems (2). Soil is a free gift of nature to human beings which provides life on Earth (7). Nonetheless, soil is usually polluted by 
anthropogenic activities, despite its importance. In soil, sources of metals could be natural such as geological weathering, atmospheric precipitation, disintegration of parent rocks because of storms, ore deposits, wind bioturbation, and waves or anthropogenic activities such as discharge of municipal waste, agricultural practices, electroplating, power transmission, industrial release, and military testing, which influence soil as a result of elevated levels of pollutants (8-11). Chemicals and pollutants that contaminate the soil enter the food chain and water bodies, and eventually, are consumed by human (7). Occurrence of heavy metals at various dumpsites and their likelihood of being transferred via soil or dust to non-polluted regions require consistent monitoring of the dumpsites, to evaluate the public safety and health risks. High levels of heavy metal pollution, followed by ecological risks, have been reported in soils from dumpsites in various countries (12-14).

Many studies have been carried out on the amount of pollutants in soils from dumpsites; however, very few studies have evaluated the effect of pollutants on dumpsites' ecology. To the best of our knowledge, there is no study on the seasonal variation and assessment of heavy metals pollution in dumpsite soils in Ilisan-Remo, Ogun State. Therefore, this study was conducted to determine the seasonal variation in concentrations of heavy metals $(\mathrm{Cd}$, $\mathrm{Cu}, \mathrm{Cr}, \mathrm{Pb}$, and $\mathrm{Ni}$ ) in soils from dumpsites around IlisanRemo, Nigeria. Furthermore, according to the obtained data, the pollution risk assessment was performed using contamination factor (CF), geo-accumulation, and ecological risk indices.

\section{Materials and Methods}

Study area

Ilisan-Remo is a town located in Irepodun district in Ikenne Local Government Area of Ogun State, Nigeria. It is located at Latitude $6^{\circ} 57^{\prime} 0^{\prime \prime} \mathrm{N}$ to $6^{\circ} 54^{\circ} 0^{\prime \prime} \mathrm{N}$ and Longitude $3^{\circ} 39^{\prime} 0^{\prime \prime} \mathrm{E}$ to $3^{\circ} 42^{\prime} 0^{\prime \prime} \mathrm{E}$ in the tropical rain forest climate zone of the country. Two major dumpsites and a control site which was about $1 \mathrm{~km}$ away from the dumpsites were selected. The dumpsites were located at Old Ilisan-lkenne road (Ilisan) and Ilisan-Iperu road (Cargo) (Figure 1).

\section{Sample collection}

During wet and dry seasons in 2018, soil samples were collected from two major dumpsites and one control site at $0-15 \mathrm{~cm}$ depth. A total of 48 samples were obtained from eight locations at each study site; composite samples were pooled from the samples. A stainless steel auger was used for sampling. All the samples were transferred to a polyethylene bag and stored under cool condition in the laboratory until analysis. In the laboratory, samples were air-dried and sieved through a 2-mm stainless sieve to remove sharp objects and debris. The samples were further sieved through a $0.5-\mathrm{mm}$ sieve to remove large particles, and then, the mixture was homogenized.

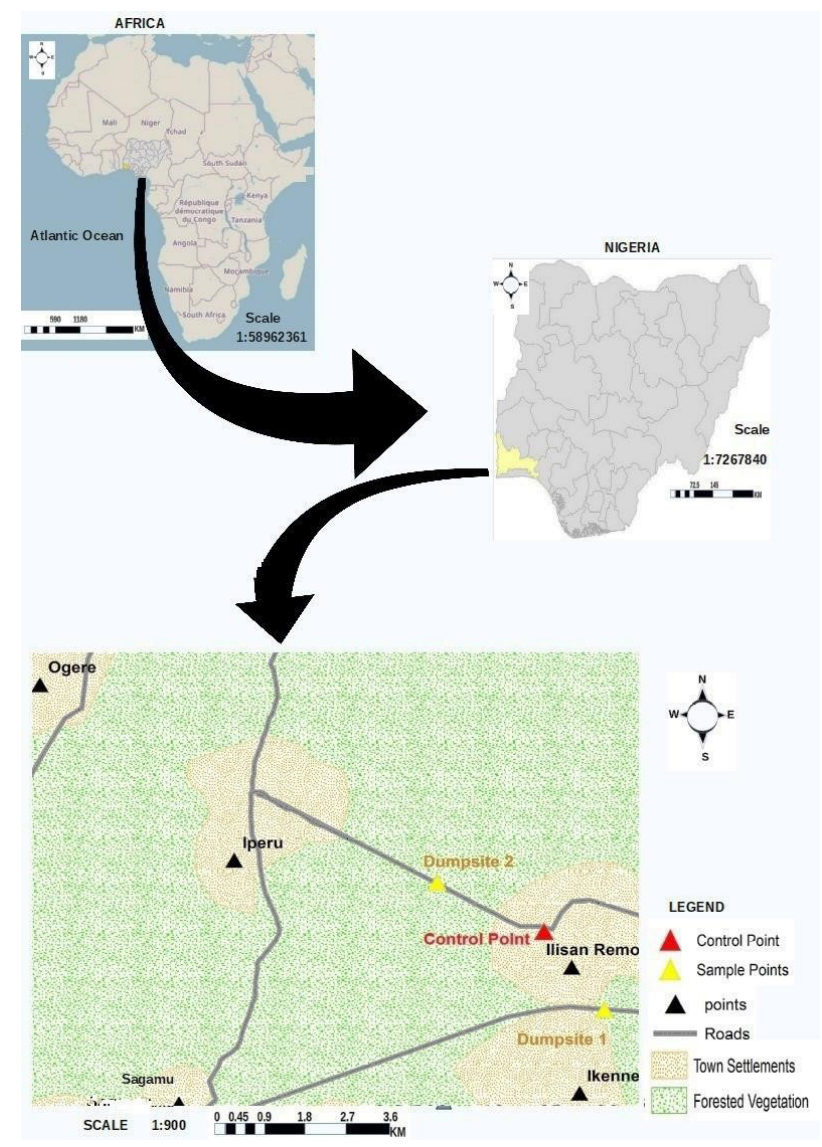

Figure 1. Geographic location of the study areas in Ogun State, Southwestern, Nigeria.

Sample preparation, digestion, and total metal concentration determination

The sampled soils were air-dried and sieved with a 2-mm stainless steel mesh. One gram of soil was digested using aqua regia $\left(\mathrm{HNO}_{3}: \mathrm{HCl}, 1: 3 \mathrm{v} / \mathrm{v}\right)$ at $150^{\circ} \mathrm{C}$ until a clear digest was obtained. Then, the mixture was centrifuged at $3500 \mathrm{~g}$ for 30 minutes and filtered using Whatman filter paper (No. 42). The final volume was adjusted to $25 \mathrm{~mL}$ with distilled deionized water and stored in polyethylene tubes maintained at $4^{\circ} \mathrm{C}$ until analysis. Chemical analyses were performed by flame atomic absorption spectrometry (FAAS). Similarly, blanks and spiked (for recovery experiments) samples were prepared and analyzed for heavy metals. All samples were determined in triplicate.

\section{Instrument}

The concentrations of $\mathrm{Cd}, \mathrm{Cu}, \mathrm{Cr}, \mathrm{Pb}$, and $\mathrm{Ni}$ were evaluated using a Buck scientific flame (air/acetylene) atomic absorption spectrometer (210 VGP model, East Norwalk, Connecticut, USA). The instrumental conditions for the analyses were set according to manufacturer's recommendations. The levels of metals in the soil samples were analyzed at maximum absorption wavelengths of $228.9,324.8,357.9,283.3$, and $341.5 \mathrm{~nm}$ for $\mathrm{Cd}, \mathrm{Cu}, \mathrm{Cr}$, $\mathrm{Pb}$, and $\mathrm{Ni}$, respectively. 


\section{Quality assurance}

The standard solutions of metals for calibration of instrument and spiking, purchased from Sigma-Aldrich, were prepared by diluting stock solutions of $1000 \mathrm{mg} / \mathrm{L}$ for each of the evaluated metals. All glasswares and related materials used in this study were properly demineralized by soaking in $2 \mathrm{M}$ nitric acid and rinsed with distilled deionized water before use. Distilled deionized water was used in preparation of all standards and digests for metals analyses. The digestion method was validated by the recovery experiment. It was carried out by quantifying the metal concentrations of both spiked and unspiked soil samples. One gram of the soil was spiked with known concentrations of metals and subjected to digestion procedure as previously described. The recovery percentage was estimated as the following equation:

Recovery $(\%)=\frac{a-b}{c} \times 100$

Where $a$ is the level of metal in spiked sample, $b$ is the level of metal in unspiked sample, and $c$ is spike level $(\mathrm{mg} / \mathrm{L})$.

The average recovery percentages of heavy metals from spiked samples after digestion were between 87 and 102\%.

Pollution indices for analysis of heavy metals

The contamination levels of metal $(\mathrm{Cd}, \mathrm{Cu}, \mathrm{Cr}, \mathrm{Pb}$, and $\mathrm{Ni}$ ) in soils taken from both dumpsites (Cargo and Ilisan) were estimated using CF and geo-accumulation index (Igeo), as proposed by Hakanson (15) and Förstner and Müller (16), respectively. The EF, CF, and Igeo were determined using equations 2 and 4, respectively.

Contamination factor

It is applied to determine the extent of soil contamination by heavy metals. It measures the ratio of each metal to the background concentrations values. The method of
Hakanson (15) was used for interpreting the CF values.

$$
C F=C m / B m(2)
$$

Where, $\mathrm{Cm}$ is heavy metal concentration in the soil and $\mathrm{Bm}$ is background concentration of heavy metals. The Department of Petroleum Resources (DPR) standard values, shown in Table 1, were used as the background concentration values. The following criteria were applied to categorize the $\mathrm{CF}$ values as very high $\left(\mathrm{CF}_{\text {metal }} \geq 6\right)$, considerable $\left(3 \leq \mathrm{CF}_{\text {metal }}<6\right)$, moderate $\left(1 \leq \mathrm{CF}_{\text {metal }}<3\right)$, and low $\left(\mathrm{CF}_{\text {metal }}<1\right)(17)$.

\section{Pollution load index}

The pollution load index (PLI) measures the level of overall contamination in a dumpsite. It was estimated using the equation reported by Ngole and Ekosse (18) as depicted in Eq. (3):

$$
P L I=n \sqrt{C F 1 \times C F 2 \times C F 3 \ldots C F n}
$$

Where $C F$ is the contamination factor and $n$ is the number of metals. The PLI can be categorized as extremely heavy pollution $(3<\mathrm{PLI})$, heavy pollution $(2<\mathrm{PLI}<3)$, moderate pollution $(1<\mathrm{PLI}<2)$, and no pollution $(\mathrm{PLI}<1)(19)$.

Geo-accumulation index

The Igeo is applied to estimate the level of metal pollution in the soil. The Igeo enables the assessment of contamination by relating the current level with background levels, and it could also be applied to estimate the contamination of various environments (16). This index is calculated using Eq. (4):

$$
\operatorname{Igeo}=\log _{2} \frac{C n}{1.5 \times B n}(4)
$$

\begin{tabular}{|c|c|c|c|c|c|}
\hline Study Site & $\mathrm{Cd}$ & $\mathrm{Cu}$ & $\mathrm{Cr}$ & $\mathrm{Pb}$ & $\mathrm{Ni}$ \\
\hline \multicolumn{6}{|c|}{ Wet season } \\
\hline Cargo & $3.81 \pm 0.66^{b}$ & $13.40 \pm 1.03^{\mathrm{a}}$ & $30.29 \pm 4.40^{\mathrm{a}}$ & $29.18 \pm 2.66^{\mathrm{b}}$ & $11.68 \pm 1.06^{\mathrm{a}}$ \\
\hline Ilisan & $7.82 \pm 0.87^{a}$ & $9.98 \pm 1.03^{a}$ & $41.38 \pm 3.99^{a}$ & $75.76 \pm 9.12^{\mathrm{a}}$ & $6.77 \pm 1.28^{b}$ \\
\hline Control & $0.85 \pm 0.12^{c}$ & $5.08 \pm 0.71^{b}$ & $17.73 \pm 2.02^{\mathrm{b}}$ & $16.98 \pm 3.41^{\mathrm{b}}$ & $3.42 \pm 0.61^{c}$ \\
\hline \multicolumn{6}{|c|}{ Dry season } \\
\hline Cargo & $2.38 \pm 0.45^{b}$ & $21.86 \pm 3.94^{b}$ & $39.29 \pm 4.56^{\mathrm{b}}$ & $38.03 \pm 4.12^{\mathrm{b}}$ & $14.55 \pm 0.93^{\mathrm{a}}$ \\
\hline Ilisan & $14.26 \pm 1.53^{\mathrm{a}}$ & $55.33 \pm 1.91^{\mathrm{a}}$ & $60.13 \pm 3.61^{\mathrm{a}}$ & $106.45 \pm 8.51^{\mathrm{a}}$ & $8.06 \pm 0.59^{b}$ \\
\hline Control & $0.00 \pm 0.00^{c}$ & $3.52 \pm 0.21^{c}$ & $18.87 \pm 2.82^{\mathrm{c}}$ & $13.16 \pm 2.44^{c}$ & $0.00 \pm 0.00^{c}$ \\
\hline WHO* & 3 & 100 & 100 & 100 & 50 \\
\hline $\mathrm{EU}^{\#}$ & 3.00 & 140 & 150 & 300 & 75 \\
\hline DPR (Target) $)^{\# \#}$ & 0.80 & 36 & 100 & 85.0 & 35.0 \\
\hline DPR (Intervention)"\# & 17.0 & 190 & 380 & 530 & 210 \\
\hline
\end{tabular}

Table 1. Heavy metal concentrations ( $\mathrm{mg} / \mathrm{kg}$ dry soil) in soils from the study sites during wet and dry seasons

Note: Values are shown as mean + Standard Deviation (SD); $\mathrm{n}=3$ and values with different letters within the same season on the same column are significantly different at $P<0.05$.

WHO: The World Health Organization, EU: The European Union, DPR: Department of Petroleum Resources.

"WHO (20), " EU (21), "\#DPR (22). 
Where, $C n$ is heavy metal concentration in the soil and $B n$ is mean background metal concentration, and 1.5 is the background correction factor. The World mean metal levels in $\mathrm{mg} / \mathrm{kg}$ ( 0.30 for $\mathrm{Cd}, 45$ for $\mathrm{Cu}, 90$ for $\mathrm{Cr}, 20$ for $\mathrm{Pb}$, and 68 for $\mathrm{Ni}$ ) in the earth's crust were used as reference levels (23). The Igeo for metals is classified as follows: extremely polluted (Igeo $\geq 5$, Class 6 ), heavily to extremely polluted $(4<$ Igeo $\leq 5$, Class 5$)$, heavily polluted $(3<$ Igeo $\leq 4$, Class 4$)$, moderately to heavily polluted $(2<$ Igeo $\leq 3$, Class $3)$, moderately polluted ( $1<$ Igeo $\leq 2$, Class 2$)$, unpolluted to moderately polluted $(0<$ Igeo $\leq 1$, Class 1$)$, and unpolluted (Igeo $\leq 0$, Class 0) (16).

\section{Ecological risk index}

This index expresses the ecological risk $\left(\mathrm{E}_{\mathrm{r}}\right)$ associated with a given contaminant. It is the ratio of the toxic response factor to the CF for a given pollutant (17). The equation is depicted as:

$\mathrm{E}_{\mathrm{r}}=\mathrm{T}_{\mathrm{r}} \times \mathrm{C}_{\mathrm{f}}(5)$

Where $T_{r}$ is the toxic response factor and $C_{f}$ is the contamination factor. The values used for the risk factors for each metal are $(\mathrm{Cd}=30, \mathrm{Cu}=5, \mathrm{Cr}=2, \mathrm{~Pb}=5$, and $\mathrm{Ni}=5)$. Ecological risk is categorized as very high $\left(\mathrm{E}_{\mathrm{r}} \geq 320\right)$, high potential $\left(160 \leq \mathrm{E}_{\mathrm{r}}<320\right)$, considerate potential $\left(80 \leq \mathrm{E}_{\mathrm{r}}<160\right)$, moderate potential $\left(40 \leq \mathrm{E}_{\mathrm{r}}<80\right)$, and low potential $\left(\mathrm{E}_{\mathrm{r}}<40\right)$.

The potential ecological risk index (RI) is the degree of contamination defined as the sum of the risk factors:

$R I=\sum_{i=1}^{m} E r_{i}(6)$

Where $\operatorname{Er}^{i}$ is the ecological risk factor and $m$ is the count of the heavy metal species. The potential ecological risk index is categorized as very high $(\mathrm{RI}>600)$, considerable $(300 \leq \mathrm{RI}<600)$, moderate $(150 \leq \mathrm{RI}<300)$, and low $(\mathrm{RI}<150)$ (16).

\section{Statistical analysis}

The obtained data were analyzed using analysis of variance (ANOVA) at significance level of $5 \%$ by SPSS version 22.0, and the means were separated using least significant difference (LSD). Pearson's correlation was used to examine the correlation between the concentrations of different metals. The principal component analysis (PCA) was used to extract a subset of the factors from the original variables. Kaiser-Meyer-Olkin (KMO) and the Bartlett sphericity tests were used on the basis of eigenvalue to validate the PCA.

\section{Results}

Heavy metal concentrations

The concentrations of heavy metals in both dumpsites during wet and dry seasons are shown in Table 1 . In wet season, the average concentrations of $\mathrm{Cd}, \mathrm{Cu}, \mathrm{Cr}, \mathrm{Pb}$, and $\mathrm{Ni}$ in Cargo and Ilisan dumpsites were 3.81-7.82, 9.98-13.40, 30.29-41.38, 29.18-75.76, and 6.77-11.68 $\mathrm{mg} / \mathrm{kg}$, respectively. The concentrations of $\mathrm{Cd}$ and $\mathrm{Pb}$ were significantly higher $(P<0.05)$ in Ilisan dumpsite compared with those in Cargo site. However, there were no significant differences in the levels of $\mathrm{Cu}$ and $\mathrm{Cr}$ at both sites $(P>0.05)$. Only the mean level of Cd was higher than the DPR target values in both dumpsites during wet season, while the levels of other metals were below the target values.

In dry season, the average concentrations of $\mathrm{Cd}, \mathrm{Cu}, \mathrm{Cr}$, $\mathrm{Pb}$, and $\mathrm{Ni}$ in Cargo dumpsite were $2.38 \pm 0.45,21.86 \pm$ $3.94,39.29 \pm 4.56,38.03 \pm 4.12$, and $14.55 \pm 0.93 \mathrm{mg} / \mathrm{kg}$, respectively, while in Ilisan dumpsite, they were reported $14.26 \pm 1.53,55.33 \pm 1.91,60.13 \pm 3.61,106.45 \pm 8.51$, and $8.06 \pm 0.59 \mathrm{mg} / \mathrm{kg}$, respectively. The concentrations of Cd, $\mathrm{Cu}, \mathrm{Cr}$, and $\mathrm{Pb}$ were significantly higher $(P<0.05)$ in Ilisan dumpsite compared with those in Cargo dumpsite. The mean levels of $\mathrm{Cd}, \mathrm{Cu}$, and $\mathrm{Pb}$ were very higher than the DPR target values, especially in Ilisan dumpsite, during dry season, while the levels of other metals were below the target values.

The mean levels of all heavy metals were significantly higher in both dumpsites compared with those in control site during wet and dry seasons $(P<0.05)$. Furthermore, the mean concentrations of the most metals in Cargo and Ilisan dumpsites were significantly higher during dry season, compared with wet season $(P<0.05)$. The concentrations of $\mathrm{Cd}$ and $\mathrm{Pb}$ were significantly higher in Ilisan dumpsite than those in Cargo dumpsite during both seasons $(P<0.05)$. The concentration of $\mathrm{Cd}$ was above the DPR target values in both seasons.

\section{Pollution indexes}

Contamination factor (CF)

Table 2 shows the CFs for each metal. The results show that $\mathrm{Cd}$ had the highest contamination level in Ilisan dumpsite while contamination level was low for $\mathrm{Cu}, \mathrm{Cr}, \mathrm{Pb}$, and $\mathrm{Ni}$ in both dumpsites during wet and dry seasons. The average $\mathrm{CF}$ for $\mathrm{Cd}$ and $\mathrm{Pb}$ in Cargo and Ilisan dumpsites during wet season was $4.76,0.34$ and 9.78, 0.89, respectively.

\section{Geo-accumulation index}

The Igeo was used to explain the quality of dumpsite soils. The values of Igeo from all sampling sites are presented in Figure 2. According to Table 3, the Igeo class shows that Ilisan dumpsite had strong to extreme contamination with $\mathrm{Cd}$ and $\mathrm{Pb}$ during both seasons, whereas Cargo dumpsite was strongly contaminated with $\mathrm{Cd}$ only during wet season, and contamination levels of other metals were low. The average Igeo values were ranked as: $\mathrm{Cd}>\mathrm{Pb}>\mathrm{Cu}>\mathrm{Ni}$ $>\mathrm{Cr}$ (Figure 2).

\section{Ecological indexes}

Potential ecological risk of a single metal, as well as the $\mathrm{RI}$ of combined metals were measured, and the results are 
Table 2. Contamination factor for the studied metals in llisan and Cargo dumpsites

\begin{tabular}{|c|c|c|c|c|}
\hline Metal & Season & Dumpsite & Value & CF Level \\
\hline \multirow{4}{*}{$\mathrm{Cd}$} & Wet & \multirow{2}{*}{ Cargo } & 4.76 & Considerable \\
\hline & Dry & & 2.98 & Moderate \\
\hline & Wet & \multirow{2}{*}{ Ilisan } & 9.78 & Very high \\
\hline & Dry & & 17.83 & Very high \\
\hline \multirow{4}{*}{$\mathrm{Cu}$} & Wet & \multirow{2}{*}{ Cargo } & 0.37 & Low \\
\hline & Dry & & 0.61 & Low \\
\hline & Wet & \multirow{2}{*}{ Ilisan } & 0.28 & Low \\
\hline & Dry & & 0.60 & Low \\
\hline \multirow{4}{*}{$\mathrm{Cr}$} & Wet & \multirow{2}{*}{ Cargo } & 0.30 & Low \\
\hline & Dry & & 0.39 & Low \\
\hline & Wet & \multirow{2}{*}{ Ilisan } & 0.41 & Low \\
\hline & Dry & & 0.60 & Low \\
\hline \multirow{4}{*}{$\mathrm{Pb}$} & Wet & \multirow{2}{*}{ Cargo } & 0.34 & Low \\
\hline & Dry & & 0.45 & Low \\
\hline & Wet & \multirow{2}{*}{ Ilisan } & 0.89 & Low \\
\hline & Dry & & 1.25 & Moderate \\
\hline \multirow{4}{*}{$\mathrm{Ni}$} & Wet & \multirow{2}{*}{ Cargo } & 0.33 & Low \\
\hline & Dry & & 0.41 & Low \\
\hline & Wet & \multirow{2}{*}{ Ilisan } & 0.19 & Low \\
\hline & Dry & & 0.23 & Low \\
\hline
\end{tabular}

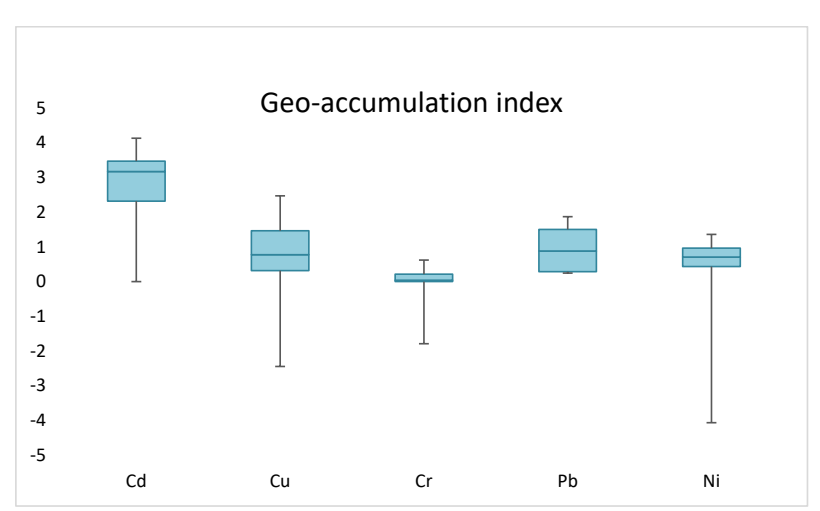

Figure 2. Variation of Igeo values in the dumpsite soils.

shown in Table 4. It was clearly shown that majority of the metals had low potential ecological risk in both dumpsites. However, the risk index was low in Cargo dumpsite, in contrast with Ilisan dumpsite, which had moderate to considerable ecological risk index in both seasons.

Identification of heavy metal sources

Pearson correlation matrix

Pearson correlation coefficient $(r)$ is used to determine the relationship between heavy metals and the sources of occurrence. Table 5 shows the correlation analysis of heavy metals in Cargo dumpsite during both seasons. There was a very strong positive correlation between $\mathrm{Ni}$ and $\mathrm{Cr}(\mathrm{r}=0.996, P<0.01)$ during wet season in Cargo dumpsite. There was also a strong negative correlation
Table 3. Geo-accumulation index class of dumpsite soils for wet and dry seasons

\begin{tabular}{llcccccc}
\hline \multirow{2}{*}{ Dumpsite } & Season & \multicolumn{6}{c}{ Class } \\
\cline { 3 - 7 } & & $\mathbf{C d}$ & $\mathbf{C u}$ & $\mathbf{C r}$ & $\mathbf{P b}$ & NI \\
\hline \multirow{2}{*}{ Cargo } & Wet & 3 & 0 & 0 & 0 & 0 \\
\cline { 2 - 7 } & Dry & 0 & 0 & 0 & 0 & 0 \\
\multirow{3}{*}{ Ilisan } & Wet & 4 & 0 & 0 & 1 & 0 \\
\cline { 2 - 7 } & Dry & 3 & 0 & 0 & 2 & 0 \\
\hline
\end{tabular}

Extremely polluted (Igeo $\geq 5$, Class 6 ), heavily to extremely polluted $(4<$ lgeo $\leq 5$, Class 5$)$, heavily polluted $(3<$ lgeo $\leq 4$, Class 4$)$, moderately to heavily polluted $(2<$ lgeo $\leq 3$, Class 3$)$, moderately polluted $(1<$ geo $\leq 2$, Class 2$)$, unpolluted to moderately polluted $(0<$ geo $\leq 1$, Class 1$)$, and unpolluted (Igeo $\leq 0$, Class 0) (16).

between $\mathrm{Pb}$ and $\mathrm{Cr}(\mathrm{r}=0.957, P<0.05)$ in Cargo dumpsite during dry season.

The correlation analysis of heavy metals in Ilisan dumpsite during wet and dry seasons is shown in Table 6 . The results showed a very strong positive correlation between $\mathrm{Pb}$ and $\mathrm{Cd}(\mathrm{r}=0.994, \mathrm{P}<0.01)$ during wet season. In dry season, there was a very strong positive correlation between $\mathrm{Cu}$ and $\mathrm{Cd}(\mathrm{r}=0.980, P<0.05)$, while there was a strong negative correlation between $\mathrm{Ni}$ and $\mathrm{Cr}(\mathrm{r}=0.971$, $P<0.05)$ in Ilisan dumpsite. The other correlations were not significant.

\section{Principal component analysis}

PCA was applied to obtain the validity of the source identification of heavy metals pollution in the dumpsites using $\mathrm{KMO}$ and its significance was determined using Bartlett's test. Components loadings are categorized as strong (>0.75), moderate $(0.75-0.50)$, and weak $(0.50$ $0.30)$.

The results of PCA, including eigenvalues, variance, and communalities for Cargo and Ilisan dumpsites are shown in Tables 7 and 8, respectively. Table 7 shows two principal components (PC1 and PC2) on Cargo dumpsite. In wet season, PC1 accounted for $79.2 \%$ of the total variance, while $\mathrm{Cd}, \mathrm{Cu}$, and $\mathrm{Pb}$ indicated a high positive loading ranged from 0.942 to 0.987 . In dry season, PC1 accounted for $58.4 \%$ of the total variance while $\mathrm{Cr}$ and $\mathrm{Pb}$ indicated a strong loading. Table 8 shows two principal components (PC1 and PC2) on Ilisan dumpsite with eigenvalue greater than 1 , which accounted for $82.8 \%$ of the total variance during dry season, and $89.2 \%$ of the total variance during wet season, indicating a strong positive loading of $\mathrm{Cd}$ and $\mathrm{Cr}$ (0.903-0.923) and a moderate loading of $\mathrm{Cu}$ (0.698).

\section{Discussion}

Heavy metal concentrations

The mean concentrations of $\mathrm{Cd}$ in this study, were higher than 0.18 to $2.60 \mathrm{mg} / \mathrm{kg}$, which was reported by Amadi and Nwankwoala (24). The concentrations of Cd reported by Victoria and Lajide, were considerably higher than 
Table 4. Potential ecological risks index of heavy metals in soil during wet and dry seasons

\begin{tabular}{|c|c|c|c|c|c|c|c|}
\hline \multirow{2}{*}{ Location } & \multicolumn{5}{|c|}{ Potential ecological risk factor (Er') } & \multirow{2}{*}{$\mathbf{R I}$} & \multirow{2}{*}{ Risk grade } \\
\hline & $\mathrm{Cd}$ & $\mathrm{Cu}$ & $\mathrm{Cr}$ & $\mathrm{Pb}$ & $\mathrm{Ni}$ & & \\
\hline \multicolumn{8}{|c|}{ Wet season } \\
\hline Cargo & 142.80 & 1.85 & 0.78 & 1.70 & 1.65 & 148.78 & Low ecological risk \\
\hline \multirow[t]{2}{*}{ Ilisan } & 293.40 & 1.40 & 0.82 & 4.45 & 0.95 & 301.02 & Considerable ecological risk \\
\hline & Considerable to high & Low & Low & Low & Low & & \\
\hline \multicolumn{8}{|c|}{ Dry season } \\
\hline Cargo & 89.40 & 3.05 & 0.78 & 2.25 & 0.65 & 96.13 & Low ecological risk \\
\hline \multirow[t]{2}{*}{ Ilisan } & 159.90 & 7.70 & 1.20 & 6.25 & 1.15 & 176.2 & Moderate ecological risk \\
\hline & Considerable & Low & Low & Low & Low & & \\
\hline
\end{tabular}

RI: Ecological risk index.

Table 5. Correlation matrix of heavy metals in Cargo dumpsite during wet and dry seasons

\begin{tabular}{|c|c|c|c|c|c|}
\hline & $\mathrm{Cd}$ & $\mathrm{Cu}$ & $\mathrm{Cr}$ & $\mathrm{Pb}$ & $\mathrm{Ni}$ \\
\hline \multicolumn{6}{|c|}{ Wet season } \\
\hline $\mathrm{Cd}$ & 1 & & & & \\
\hline $\mathrm{Cu}$ & 0.268 & 1 & & & \\
\hline $\mathrm{Cr}$ & 0.889 & 0.680 & 1 & & \\
\hline $\mathrm{Pb}$ & 0.547 & 0.305 & 0.553 & 1 & \\
\hline $\mathrm{Ni}$ & 0.926 & 0.612 & $0.996 * *$ & 0.571 & 1 \\
\hline \multicolumn{6}{|c|}{ Dry season } \\
\hline $\mathrm{Cd}$ & 1 & & & & \\
\hline $\mathrm{Cu}$ & 0.824 & 1 & & & \\
\hline $\mathrm{Cr}$ & -0.775 & -0.910 & 1 & & \\
\hline $\mathrm{Pb}$ & 0.918 & 0.894 & $-0.957^{*}$ & 1 & \\
\hline $\mathrm{Ni}$ & 0.948 & 0.606 & -0.619 & 0.820 & 1 \\
\hline
\end{tabular}

${ }^{*}$ Correlation is significant at $P \leq 0.05$ (2-tailed).

${ }^{* *}$ Correlation is significant at $P \leq 0.01$ (2-tailed).

Table 6. Correlation matrix of heavy metals in llisan dumpsite during wet and dry seasons

\begin{tabular}{|c|c|c|c|c|c|}
\hline & Cd & $\mathrm{Cu}$ & $\mathrm{Cr}$ & $\mathrm{Pb}$ & $\mathbf{N i}$ \\
\hline \multicolumn{6}{|c|}{ Wet season } \\
\hline $\mathrm{Cd}$ & 1 & & & & \\
\hline $\mathrm{Cu}$ & 0.601 & 1 & & & \\
\hline $\mathrm{Cr}$ & 0.470 & 0.428 & 1 & & \\
\hline $\mathrm{Pb}$ & $0.994 * *$ & 0.553 & 0.374 & 1 & \\
\hline $\mathrm{Ni}$ & -0.739 & -0.609 & 0.169 & 0.784 & 1 \\
\hline \multicolumn{6}{|c|}{ Dry season } \\
\hline $\mathrm{Cd}$ & 1 & & & & \\
\hline $\mathrm{Cu}$ & $0.980 *$ & 1 & & & \\
\hline $\mathrm{Cr}$ & -0.292 & -0.111 & 1 & & \\
\hline $\mathrm{Pb}$ & -0.159 & -0.160 & -0.314 & 1 & \\
\hline $\mathrm{Ni}$ & 0.210 & 0.015 & $-0.971 *$ & 0.118 & 1 \\
\hline
\end{tabular}

${ }^{*}$ Correlation is significant at $P \leq 0.05$ (2-tailed).

${ }^{* *}$ Correlation is significant at $P \leq 0.01$ (2-tailed). 
Table 7. Varimax rotated component matrix and total variance of heavy metals in Cargo dumpsite for wet and dry seasons

\begin{tabular}{|c|c|c|c|}
\hline \multirow{2}{*}{ Variable } & \multicolumn{2}{|c|}{ Rotated Component Matrix } & \multirow{2}{*}{ Communalities } \\
\hline & PC1 & PC2 & \\
\hline \multicolumn{4}{|c|}{ Wet season } \\
\hline $\mathrm{Cd}$ & 0.987 & & 0.995 \\
\hline $\mathrm{Cu}$ & 0.970 & & 1.00 \\
\hline $\mathrm{Cr}$ & 0.619 & 0.778 & 0.988 \\
\hline $\mathrm{Pb}$ & 0.942 & 0.335 & 1.00 \\
\hline $\mathrm{Ni}$ & & 0.998 & 0.994 \\
\hline Eigenvalue & 3.962 & 1.014 & \\
\hline Total variance (\%) & 79.248 & 20.275 & \\
\hline Cumulative (\%) & 79.248 & 99.523 & \\
\hline \multicolumn{4}{|c|}{ Dry season } \\
\hline $\mathrm{Cd}$ & & & 0.993 \\
\hline $\mathrm{Cu}$ & -0.509 & & 0.281 \\
\hline $\mathrm{Cr}$ & 0.698 & -0.624 & 0.877 \\
\hline $\mathrm{Pb}$ & 0.985 & 0.996 & 0.974 \\
\hline $\mathrm{Ni}$ & -0.993 & & 0.999 \\
\hline Eigenvalue & 2.921 & 1.202 & \\
\hline Total variance (\%) & 58.422 & 24.045 & \\
\hline Cumulative (\%) & 58.422 & 82.467 & \\
\hline
\end{tabular}

Table 8. Varimax rotated component matrix and total variance of heavy metals in llisan dumpsite for wet and dry seasons

\begin{tabular}{|c|c|c|c|}
\hline \multirow{2}{*}{ Variable } & \multicolumn{2}{|c|}{ Rotated Component Matrix } & \multirow{2}{*}{ Communalities } \\
\hline & PC1 & PC2 & \\
\hline \multicolumn{4}{|c|}{ Wet season } \\
\hline $\mathrm{Cd}$ & 0.903 & 0.347 & 0.935 \\
\hline $\mathrm{Cu}$ & 0.698 & 0.368 & 0.622 \\
\hline $\mathrm{Cr}$ & & 0.991 & 0.998 \\
\hline $\mathrm{Pb}$ & 0.923 & & 0.913 \\
\hline $\mathrm{Ni}$ & -0.953 & & 0.993 \\
\hline Eigenvalue & 3.298 & 1.164 & \\
\hline Total variance (\%) & 65.951 & 23.281 & \\
\hline Cumulative (\%) & 65.952 & 89.232 & \\
\hline \multicolumn{4}{|c|}{ Dry season } \\
\hline $\mathrm{Cd}$ & & 0.981 & 0.986 \\
\hline $\mathrm{Cu}$ & & 0.977 & 0.955 \\
\hline $\mathrm{Cr}$ & -0.985 & & 0.993 \\
\hline $\mathrm{Pb}$ & 0.443 & -0.334 & 0.308 \\
\hline $\mathrm{Ni}$ & 0.942 & & 0.899 \\
\hline Eigenvalue & 2.303 & 1.838 & \\
\hline Total variance (\%) & 46.051 & 36.762 & \\
\hline Cumulative (\%) & 46.051 & 82.813 & \\
\hline
\end{tabular}

The results of Kaiser-Meyer-Olkin (KMO) and Bartlett's sphericity tests are significant at $P<0.01$. Extraction method: Principal component analysis. Rotation method: Varimax with Kaiser Normalization. Rotation converges after 3 iterations. those recorded in soil from the dumpsites studied in Ilisan (25). The higher Cd levels in the dumpsites could be due to disposal of lubricating oil, vehicles wheels, and metal alloys used in automobiles on the sites (26).

The higher $\mathrm{Cu}$ levels during dry season can be attributed to run-off during wet season (27). The higher concentrations of $\mathrm{Cu}$ in the dumpsites compared to the control site could be due to inappropriate disposal of lubricants and automobile wastes (28). The values obtained for $\mathrm{Cu}$ in the dumpsites (9.98-55.33 $\mathrm{mg} / \mathrm{kg}$ ) and control site (3.52$5.08 \mathrm{mg} / \mathrm{kg}$ ) were within the uncontaminated soil range $(2-100 \mathrm{mg} / \mathrm{kg})$ as reported by Nangia (29). Also, the concentrations of $\mathrm{Cu}$ were higher than those reported by Olufunmilayo et al, which ranged 1.71 to $3.30 \mathrm{mg} / \mathrm{kg}$ in dumpsite soil and 0.27 to $1.56 \mathrm{mg} / \mathrm{kg}$ in control site soils in Iree, Osun State, Nigeria (30). Brady and Weil reported high concentrations of $\mathrm{Cu}$ ranging from $59.32 \pm 0.01$ to $96.13 \pm 0.26 \mathrm{mg} / \mathrm{kg}$ and $40.16 \pm 0.01$ to $62.10 \pm 0.01 \mathrm{mg} / \mathrm{kg}$ during dry and wet seasons, respectively (31), which were higher than those reported in this study.

The high Cr concentrations, especially during dry season, could be attributed to disposal of wastes containing high levels of $\mathrm{Cr}$ (32). It can also be due to the cleansing effects of rainfall during the rainy season or the availability of this heavy metal at depth of $0-15 \mathrm{~cm}$ from automobile emissions and other human activities (33). The $\mathrm{Cr}$ concentrations obtained from the dumpsite soils in this study were lower than $120.28 \pm 103.34 \mathrm{mg} / \mathrm{kg}$, which was reported by Ediene and Umoetok (32), and also lower than $59.14 \pm$ 0.14 to $102.50 \pm 0.01 \mathrm{mg} / \mathrm{kg}$ and $49.96 \pm 0.3$ to $89.46 \pm 0.03$ $\mathrm{mg} / \mathrm{kg}$ during dry and wet seasons, respectively, reported by Yahaya et al (27). Meanwhile, the values were higher than those ( 0.1 to $0.5 \mathrm{mg} / \mathrm{kg}$ ) reported by Dauda (34). The concentrations of $\mathrm{Cr}(15.30$ to $62.75 \mathrm{mg} / \mathrm{kg})$ recorded by Adelekan and Alawode (35), are similar to those obtained in this study. Although, Cr toxicity is relatively rare in the environment, it still poses some health risks to humans because it accumulates in skin, muscles, lungs, and liver, leading to various health problems (36).

Kabir et al (37), reported $\mathrm{Pb}$ concentrations of 65.80 to $624.50 \mathrm{mg} / \mathrm{kg}$, which are higher than those reported in the present study. Similarly, the values reported in this study are lower than that $(1162 \mathrm{mg} / \mathrm{kg})$ obtained by Nwachukwu et al (38) in soil from South-East, Nigeria. The values of $\mathrm{Pb}$ in the studied dumpsites was higher than the DPR target values which could be due to high quantities of dumped scraped lead proof pipes, paint materials and batteries in the dumpsites.

The values obtained for $\mathrm{Ni}$ in this study were similar to those obtained by Adelekan and Alawode (35), ranged 4.35 to $49.80 \mathrm{mg} / \mathrm{kg}$. However, they were much lower compared with the mean concentrations of $\mathrm{Ni}(26.3 \pm 51.1$ $\mathrm{mg} / \mathrm{kg}$ ) reported by Olayiwola and Onwordi (39).

Pollution indices

The CF showed that the dumpsites contained considerable 
to very high levels of $\mathrm{Cd}$ (Table 2). The CF values obtained for the remaining four metals indicated that the dumpsites were lowly polluted with these metals. The PLI less than 1 in the Cargo dumpsite during both seasons suggests no pollution, while PLI $>1$ obtained in the Ilisan dumpsite during dry season, suggests moderate pollution of the dumpsite.

The Igeo revealed that the two dumpsites studied during both seasons, related to all the metals, fell into class 0 (unpolluted), except for $\mathrm{Cd}$ in both sites and $\mathrm{Pb}$ in Ilisan dumpsite (Table 3, Figure 2). The pattern of Cd contamination as indicated by the Igeo class was similar to that reported by Ihedioha et al (40).

The values of the ecological risk factor $\left(\mathrm{Er}^{\mathrm{i}}\right)$ for $\mathrm{Cu}, \mathrm{Cr}, \mathrm{Pb}$, and $\mathrm{Ni}$ were below 40, indicating low potential ecological risk in the two dumpsites during wet and dry seasons. However, the relatively high Er ${ }^{\mathrm{i}}$ of Cd (142.80 to 293.40) in Cargo and Ilisan dumpsites suggests that Cd could pose a considerable to high ecological risk to the dumpsites (Table 4), which is consistent with the results reported by Ihedioha et al (40). In addition, the ecological RI was used to determine the overall potential risk, indicating low risk of Cargo dumpsite during both seasons, in contrast to Ilisan dumpsite with considerable risk during wet season and moderate risk during dry season, which is consistent with the results reported by Ihedioha et al (40).

The strong positive correlations between some heavy metals ( $\mathrm{Ni}$ and $\mathrm{Cr}, \mathrm{Pb}$ and $\mathrm{Cd}, \mathrm{Cd}$ and $\mathrm{Cu}$ ) in both dumpsites for both seasons indicate that these metals are from related anthropogenic activities. The strong negative correlations between $\mathrm{Ni}$ and $\mathrm{Cr}$, and $\mathrm{Pb}$ and $\mathrm{Cr}$ shows that their presence in both dumpsites during dry season were not from related activities or sources, rather they were from different sources.

The correlations observed in this study are similar to those reported for $\mathrm{Cd}$ and $\mathrm{Pb}(\mathrm{r}=0.731)$ by Mugoša et al (41). The correlation between $\mathrm{Cd}$ and $\mathrm{Cu}$ is consistent with that between $\mathrm{Pb}$ and $\mathrm{Cu}(\mathrm{r}=0.831)$ reported by Yusuf et al (42). Table 7 and 8 show that the eigenvalue for two principal components during both seasons was above 1 . The observed positive loading for $\mathrm{Cd}, \mathrm{Cr}$, and $\mathrm{Pb}$ in Cargo dumpsite, and for $\mathrm{Cd}, \mathrm{Cu}, \mathrm{Pb}$, and $\mathrm{Ni}$ in Ilisan dumpsite show that the metals are from anthropogenic activities. This could be related to the disposal of automobile scrap parts, discharge of traffic emissions, cooking utensils and chromium plated materials on the dumpsite. The negative loading observed for $\mathrm{Ni}$ show that it is from different anthropogenic activities.

\section{Conclusion}

This study was conducted to evaluate the metal concentrations in Cargo and Ilisan dumpsites during wet and dry seasons. For this purpose, the dumpsites were accessed for pollution using pollution indices. The total metal concentrations obtained for $\mathrm{Cd} \mathrm{Cu}, \mathrm{Cr}, \mathrm{Pb}$, and $\mathrm{Ni}$ were higher during dry season compared with wet season. Their mean values were found to be above the DPR target limit in Nigerian soils. The CF, Igeo, and ecological risk index suggest a low to heavy pollution of the Cargo and Ilisan dumpsites, especially with Cd during the two seasons. The results of Pearson's correlation and PCA show that most of the metals are most likely to be related to the same anthropogenic sources. In Cargo dumpsite, Cd, Cr, and $\mathrm{Pb}$ are most likely to be from anthropogenic sources, while $\mathrm{Cu}$ and $\mathrm{Ni}$ are from natural sources, while on Ilisan dumpsite $\mathrm{Cd}, \mathrm{Cu}, \mathrm{Pb}$, and $\mathrm{Ni}$ were from anthropogenic sources and $\mathrm{Cr}$ was from natural source. The results of PCA indicated that the dumpsite was much more polluted with Cd.

These metals studied, especially Cd, could pose serious threats to human health, if transferred along food chain within the ecosystem. The results of this study could help the Government to take appropriate measures in preventing further pollution of the dumpsites. Furthermore, appropriate measures should be implemented to manage these dumpsites for achieving positive outcomes on population health.

\section{Acknowledgments}

The authors would like to appreciate Ms. Nwokocha Amarachi, Department of Agriculture and Industrial Technology, Mr. Jegede Olaoluwa, Mr. Adaramola Banji, and Ms. Abioye Oyeleye, Department of Basic Sciences, Mr. Ayinde Adebara, Department of Biochemistry, and Dr. Akeredolu Abolanle, Department of Microbiology, Babcock University, Ilisan-Remo, Ogun State, who supported them to perform this study.

\section{Ethical issues}

The authors have critically observed ethical issues and no data from this manuscript has been or will be published separately elsewhere.

\section{Competing interests}

The authors declare that they have no competing interests.

\section{Authors' contributions}

Oluwatosin Shokunbi collected the soil samples, carried out the experiments, wrote the first draft of the manuscript; Olumuyiwa Ajayi designed and supervised the experiment, and edited the manuscript; Olutayo Shokunbi participated in sample collection, carried out the experiment, and reviewed the final version of manuscript. All authors read and approved the manuscript before submission.

\section{References}

1. Khan MA, Ghouri AM. Environmental pollution: its effects on life and its remedies. Res World - J Arts Sci Commer 2011; 2(2): 276-85.

2. Begum A, Ramaiah M, Khan I, Veena K. Heavy metal pollution and chemical profile of Cauvery River 
water. Journal of Chemistry. 2009; 6(1): 47-52. doi: $10.1155 / 2009 / 154610$.

3. Papafilippaki AK, Kotti ME, Stavroulakis GG. Seasonal variations in dissolved heavy metals in the Keritis river, Chania, Greece. Global NEST Journal 2008; 10(3): 320-5. doi: 10.30955/gnj.000528.

4. Fong FT, Chee PS, Mahmood AA, Tahir NM. Possible source and pattern distribution of heavy metals content in urban soil at Kuala Terengganu town center. Malaysian J Anal Sci 2008; 12(2): 458-67.

5. Qishlaqi A, Moore F. Statistical analysis of accumulation and sources of heavy metals occurrence in agricultural soils of Khoshk river banks, Shiraz, Iran. Am Eurasian J Agric Environ Sci 2007; 2(5): 565-73.

6. Bose B. Developments in Physiology, Biochemistry and Molecular Biology of Plants. 2nd ed. New Delhi, India: New India Publishing Agency; 2005. p. 105.

7. Misra S, Mani D. Soil pollution. New Delhi, India: S. B Nangia APH Publishing Corporation; 2009. p. 29-59.

8. van Straalen, Krivolutsky DA. Bioindicator Systems for Soil Pollution. Dordrecht: Kluwer Academic Publishers; 1996. p. 1-8.

9. Sun Z, Mou X, Tong C, Wang C, Xie Z, Song H, et al. Spatial variations and bioaccumulation of heavy metals in intertidal zone of the Yellow River estuary, China. Catena 2015; 126: 43-52. doi: 10.1016/j.catena.2014.10.037.

10. Muhammad S, Shah MT, Khan S. Heavy metal concentrations in soil and wild plants growing around $\mathrm{Pb}-\mathrm{Zn}$ sulfide terrain in the Kohistan region, northern Pakistan. Microchem J 2011; 99(1): 67-75. doi: 10.1016/j. microc.2011.03.012.

11. Altin A, Filiz Z, Iscen CF. Assessment of seasonal variations of surface water quality characteristics for Porsuk Stream. Environ Monit Assess 2009; 158(1-4): 51-65. doi: 10.1007/ s10661-008-0564-3.

12. Famuyiwa AO, Lanre-Iyanda YA, Osifeso O. Impact of land use on concentrations of potentially toxic elements in urban soils of Lagos, Nigeria. J Health Pollut 2018; 8(19): 180904. doi: 10.5696/2156-9614-8.19.180904.

13. Hu Z, Wang C, Li K, Zhu X. Distribution characteristics and pollution assessment of soil heavy metals over a typical nonferrous metal mine area in Chifeng, Inner Mongolia, China. Environ Earth Sci 2018; 77(18): 638. doi: 10.1007/ s12665-018-7771-1.

14. Baghaie AH, Aghili F. Investigation of heavy metals concentration in soil around a $\mathrm{Pb}-\mathrm{Zn}$ mine and ecological risk assessment. Environ Health Eng Manag 2019; 6(3): 151-6. doi: 10.15171/ehem.2019.17.

15. Hakanson L. An ecological risk index for aquatic pollution control. A sedimentological approach. Water Res 1980; 14(8): 975-1001. doi: 10.1016/0043-1354(80)90143-8.

16. Förstner U, Müller G. Concentrations of heavy metals and polycyclic aromatic hydrocarbons in river sediments: geochemical background, man's influence and environmental impact. GeoJournal 1981; 5(5): 417-432. doi: $\quad 10.1007 / b f 02484715$.

17. Ghannem N, Gargouri D, Sarbeji MM, Yaich C, Azri C. Metal contamination of surface sediments of the SfaxChebba coastal line, Tunisia. Environ Earth Sci 2014; 72(9): 3419-27. doi: 10.1007/s12665-014-3248-z.

18. Ngole VM, Ekosse GI. Copper, nickel and zinc contamination in soils within the precincts of mining and landfilling environments. Int J Environ Sci Technol 2012; 9(3): 485-94. doi: 10.1007/s13762-012-0055-5.

19. Zarei I, Pourkhabbaz A, Khuzestani RB. An assessment of metal contamination risk in sediments of Hara Biosphere Reserve, southern Iran with a focus on application of pollution indicators. Environ Monit Assess 2014; 186(10): 6047-60. doi: 10.1007/s10661-014-3839-x.

20. Turekian KK, Wedepohl KH. Distribution of the elements in some major units of the earth's crust. Geol Soc Am Bull 1961; 72(2): 175-92.

21. World Health Organization (WHO). Standard maxima for metals in agricultural soils. Geneva: WHO; 1993.

22. European Commission. Heavy Metals in Waste. Denmark: COWI; 2002.

23. Department of Petroleum Resources (DPR). Environmental Guidelines and Standards for the Petroleum Industry in Nigeria (EGASPIN). Nigeria: Ministry of Petroleum and Natural Resources, Department of Petroleum Resources; 2002.

24. Amadi Akobundu N, Nwankwoala HO. Evaluation of heavy metal in soils from Enyimba dumpsite in Aba, Southeastern Nigeria using contamination factor and geo-accumulation index. Energy Environ Sci 2013; 3(1): 125-34. doi: 10.5539/ eer.v3n1p125.

25. Victoria AO, Lajide L. Surface soil pollution by heavy metals: a case study of two refuse dumpsites in Akure metropolis. Int J Sci Technol Res 2015; 4(3): 71-4.

26. Amusan AA, Ige DV, Olawale R. Characteristics of soils and crops' uptake of metals in municipal waste dump sites in Nigeria. J Hum Ecol 2005; 17(3): 167-71. doi: 10.1080/09709274.2005.11905775

27. Yahaya MI, Mohammad S, Abdullahi BK. Seasonal variations of heavy metals concentration in abattoir dumping site soil in Nigeria. J Appl Sci Environ Manage 2009; 13(4): 9-13. doi: 10.4314/jasem.v13i4.55387.

28. Alloway BJ, Ayres DC. Chemical Principles of Environmental Pollution. 2nd ed. London: Blackie Academic \& Professional; 1997. p. 190-242.

29. Nangia SB. Soil Pollution. New Delhi: Ashish Publishing House; 1991.

30. Olufunmilayo OO, Oludare AH, Oluwatoyin D. Determination of concentrations of heavy metals in municipal dumpsite soil and plants at Oke-ogi, Iree, Nigeria. International Research Journal of Pure and Applied Chemistry 2014; 656-69. doi: 10.9734/IRJPAC/2014/11063.

31. Brady NC, Weil RR. The Nature and Properties of Soils. 14th ed. New York, USA: Prentice Hall; 2008. p. 965.

32. Ediene VF, Umoetok SB. Concentration of heavy metals in soils at the municipal dumpsite in Calabar metropolis. Asian J Environ Ecol 2017; 3(2): 1-11. doi: 10.9734/ ajee/2017/34236.

33. Ideriah TJ, David-Omiema S, Ogbonna DN. Distribution of heavy metals in water and sediment along Abonnema Shoreline, Nigeria. Resources and Environment 2012; 2(1): 33-40. doi: 10.5923/j.re.20120201.05.

34. Dauda BE, Paiko YB, Yisa J, Salihu SO, Agboola JO. Determination of heavy metals in soil in the vicinity of a dumpsite in Ketaren Gwari Minna. Int J Sci Nat 2011; 2(2): 411-3.

35. Adelekan BA, Alawode AO. Contributions of municipal refuse dumps to heavy metals concentrations in soil profile and groundwater in Ibadan Nigeria. J Appl Biosci 2011; 40: 
2727-37.

36. Reyes-Gutiérrez LR, Romero-Guzmán ET, Cabral-Prieto A, Rodríguez-Castillo R. Characterization of chromium in contaminated soil studied by SEM, EDS, XRD and Mössbauer spectroscopy. Journal of Minerals \& Materials Characterization \& Engineering 2007; 7(1): 59-70.

37. Kabir MM, Fakhruddin AN, Chowdhury MA, Fardous Z, Islam R. Characterization of tannery effluents of Hazaribagh area, Dhaka, Bangladesh. Pollution 2017; 3(3): 395-406.

38. Nwachukwu MA, Feng H, Alinnor J. Trace metal dispersion in soil from auto-mechanic village to urban residential areas in Owerri, Nigeria. Procedia Environ Scie 2011; 4: 310-22. doi: 10.1016/j.proenv.2011.03.036.

39. Abidemi OO, Onwordi CT. Environmental fate of heavy metals in soil of Ido-Osun waste dump site, Osogbo, Osun,
Nigeria. American Journal of Environmental Protection 2015; 3(1): 1-4. doi:10.12691/env-3-1-1.

40. Ihedioha JN, Ukoha PO, Ekere NR. Ecological and human health risk assessment of heavy metal contamination in soil of a municipal solid waste dump in Uyo, Nigeria. Environ Geochem Health 2017; 39(3): 497-515. doi: 10.1007/ s10653-016-9830-4.

41. Mugoša B, Đurović D, Nedović-Vuković M, BarjaktarovićLabović S, Vrvić M. Assessment of ecological risk of heavy metal contamination in coastal municipalities of Montenegro. Int J Environ Res Public Health 2016; 13(4): 393. doi: 10.3390/ijerph13040393.

42. Yusuf S, Audu AA, Waziri M. Evaluation of heavy metals, dissolved organic phosphorus (DOP) and nitrogen (DON) in three wetlands of Northern Nigeria. J Chem Soc Nigeria 2018; 43(3): 656-66. 